\title{
Flood Water Management from Hill Torrents of Pakistan for Agriculture Livelihood Improvement
}

\author{
Talat Farid Ahmed ${ }^{1 *}$, Shamim-ul-Sibtain Shah ${ }^{1}$, Ashfaq Ahmed Sheikh ${ }^{2}$, Hashim Nisar Hashmi ${ }^{3}$, \\ Muhammad Atiqullah Khan ${ }^{1}$ and Muhammad Azeem Afzal ${ }^{1}$
}

${ }^{1}$ Farm Operations and Services, National Agricultural Research Centre, Park Road Islamabad, Pakistan; ${ }^{2}$ CPD, Pakistan Engineering Council, Islamabad, Pakistan; ${ }^{3}$ Faculty of Engineering, Muslim Youth University, Islamabad, Pakistan.

Abstract | Mithawan Hill Torrent is one of the thirteen Major Hill Torrents in District: Dera Ghazi Khan of Pakistan. The study presents management solution of Mithawan hill torrent flood water. The impact of constructing main dispersion distributor and management structures for equitable distribution in the Pachad area i.e. the plain area in the foot hills of Koh-e-Suleiman has been investigated. Management solution are proposed with design aspects without causing damages to prevailing infrastructure, without stoppage of Canal breaches, minimized damages to standing crops in command area, and will ensure improved irrigation supplies in the Kob e Suleman (Pachad) area, enhancement in economic condition of the area, stable farming in the Pachad area and providing maximum use of flood water for agriculture to increase production and ultimately for socio-economic uplift of the area. The data regarding flood levels and topographic maps have collected from Irrigation and NESPAK departments. It is concluded that by the Construction of Management Structures for Hill Torrents will resulted; enhanced cultivable area i.e. over 90,000 acres annually, resulted thousands of families would be beneficial, getting equitable irrigation water availability and maximum water would be utilized.

Received | January 01, 2020; Accepted | March 15, 2021; Published | June 18, 2021

${ }^{*}$ Correspondence $\mid$ Talat Farid Ahmed, Farm Operations and Services, National Agricultural Research Centre, Park Road Islamabad, Pakistan; Email: tafa367@gmail.com

Citation $\mid$ Ahmed, T.F., S.S. Shah, A.A. Sheikh, H.N. Hashmi, M.A. Khan and M.A. Afzal. 2021. Flood water management from hill torrents of Pakistan for agriculture livelihood improvement. Pakistan Journal of Agricultural Research, 34(3): 438-445.

DOI | https://dx.doi.org/10.17582/journal.pjar/2021/34.3.438.445

Keywords | Hill torrents, Flood water, Pachad area, Semi arid region, Flood control

\section{Introduction}

A griculture Sector is the backbone of Pakistan's economy as it employs $50 \%$ of the total labour force of Pakistan and has $25 \%$ contribution in gross domestic products (GDP) (Economic Survey of Pakistan, 2018). Most of the crop production area of Pakistan about $60 \%$ falls in the dry region which receives an annual rainfall of less than 250 $\mathrm{mm}$. For crop production irrigation plays a vital role and Pakistan is the eminent irrigated country in the world having $160,000 \mathrm{~km}^{2}$ (16 million hectares) of irrigated land about $20 \%$ of the territory of 800,000 $\mathrm{km}^{2}$ or $76 \%$ of cultivated land subsequently. The most important goal is to maximize water use efficiency for irrigation.

The conventional water resources of Pakistan are under extreme stress and difference between supply and demand is increasing rapidly. Hill torrents flood flow provides excellent prospects for development in fulfilling the growing demand of water for agriculture. Although is a complex task to harness this flood flow potential due to high sediment load, variance with 
crop water requirements and large variation in peak to normal flows.

Out of 200 hill torrents, 13 are considered major (Mithawan Hill Torrent, Kaura Hill Torrent, Vehova, Sanghar, Sori Lound, Vidore, Sakhi Serwar, Chachar, Kaha, Pitok, Sori Shumali, Zangi and Sori Janubi), begin from Suleman Range and flow through D.G. Khan and Rajanpur Districts towards the River Indus. Total catchment area of these hill torrents is 11881 Sq. Miles, extending more than $360 \mathrm{~km}$ (200 miles) length from Ramak to Kashmore, and $25 \mathrm{Km}$ to 40 $\mathrm{Km}$ in width. The PACHAD area (Piedmont area) is the area connecting the foot hills of the Suleman Range from Ramak to Kashmore and Chashma Right Bank Canal System and D.G. Khan Canal System. The flood water from hill torrents is used for irrigation with the piedmont area, by means of dispersion structures and diversion.

The hill torrents bring shorter duration flash flood of high magnitude and velocity which cause banks and channel bed erosion due to steep gradients. High silt content in the plain areas is also deposited. The shifting of flow regime and paths of hill are linked with the silting and scouring phenomena. Due to unpredictable and erratic nature of these floods, designers and flood planners face many challenges for economic management. The PACHAD area farmers can make use of low flows of hill torrents by small earthen bunds construction; also known as gandas and High flow breach earthen diversion bunds.

Problems are faced at the canals when the total flows of onrushing torrents exceed the ability of the cross drainage works. The water gathered along the right bank of the canals cause severe breaches and inundate the command area of canal. Intense torrential flows not only destroy infrastructure, human life and property in the area but also results in the closure of canal for prolonged period. Irrigation Department has estimated that an average annual damage caused in canal command area due to hill torrents is approximately Rs. 63.00 Million. (NESPAK, 1996), In the past various efforts have been made to manage hill torrent flows but in vain because they were based on inadequate data and overall perspective of flood flows of the entire catchment were not considered.

The basic aim of the study was to manage the hill torrent water in surrounding area for irrigation purpose, the Mithawan hill torrent flood water will manage by constructing main dispersion distributor and 5 Nos. management structures for equitable distribution in the Pachad area i.e. the plain area in the foot hills of Koh-e-Suleiman.

The most suitable dam sites were identified using a relation based dam suitability analysis (RDSA) technique which considers the parameters/indicators i.e. slope, stream order, multiresolution valley bottom flatness index, terrain roughness index, closed depression, valley depth, downslope gradient difference relative to the dam wall and reservoir fitness. Two appropriate dam sites (A and B) were identified using RDSA technique having greatest collective capability. The soil erosion estimates showed an average of $75 \mathrm{t}-\mathrm{ha}-1 \mathrm{y}-1$ loss of soil in the study area. The result depicted that around 298,073 and 318,000 tons of annual average sediment yield would supply the dam A and B. The soil erosion based sediment yield confirmed the estimated life of Dam A would be 87 and Dam B would be 90 years. It is a dynamic approach and could be utilized for the selection of dam site and estimation of soil erosion for any location globally (Munir et al., 2021).

In this study hydraulic analysis software (HEC-RAS) was used for prediction of flood by means of flood wave propagation. This helps in estimating the extent of flood and the possible impact on downstream dam area. The flood scenarios were studied over human settlements, structures and plantations. The results showed that the dam break is very serious and potential management measures are necessary in order to minimize the risk. This study showed that innovative remote sensing and dam breach flood simulations can be utilized for planning to enhance the dam safety (Psomiadis et al., 2021).

A study was started to know the surface runoff potential and find out productive water harvesting sites for sustainable irrigation in the region under study by using GIS and RS techniques. Total 533 water harvesting sites were selected with a total runoff potential of more than 154 million $\mathrm{m} 3$ in hill-torrent region using geospatial modelling techniques together with ground information. 26 sites were chosen over the plain to gentle slopes in unused land below 300 $\mathrm{m}$ elevation for water harvesting interventions. The results showed that a joined floodwater management method including control of environmental 
degradation, institutional strengthening, and capacity building of the locals be adopted and also suggested for building of Cost-effective earthen water reservoirs for runoff water harvesting, which led to the effective development of region in future (Farooq et al., 2020).

A review study was carried out to know the creation and life of an operational crisis management centre for effective flood events handling by means of feedbacks. Three points were under analysis; the legal framework and attitude growths, feedbacks about flood event crisis handling and measures to improve crisis aspects in accordance with given standards. A specific focus was given to a platform development to support Emergency handling, mainly flood events; development of new plans for use of sets of highresolution flood maps and virtual rainfall gauges; municipality promise on tailing high-standard of updates and application of new technologies in crisis management centre (Dorgigné et al., 2018).

A study was conducted for the calibration and development of a dual drainage watershed model under various storm conditions. Urban systems of storm water drainage might undergo various flow regimes including reverse flow, surcharging, backwater and surface ponding. The efficiency coefficient values were 0.86 and 0.82 , respectively which were the observed and computed maximum total flow volumes for 02 calibrated events yielded from the developed model (Randall et al., 2017).

A study was done to investigate the Global Sensitivity Analysis (GSA) of 2D shallow water equations based on High Resolution (HR) flood model by using High Resolution classified topographic data. The objective of this analysis was to produce sensitivity maps which were to be used on Sobol index estimations. The effects of parameters like error in measurement, the intensity of particulars of above-ground elements representation and the spatial discretization resolution were studied. The results indicated that generated sensitivity maps reflected the major response of model ranges related to HR measurement errors, as HR topographic data were used. In addition to that, the spatial variability of the ranking was enhanced (Abily et al., 2016).

The risk related to local plus widespread flooding specially on rivers and coasts was assessed. Whereas a new method for accommodation of extensive flood risk management was developed. This method is very useful for designing flood defence system and for calculation of economic losses and other effect caused by the flood over the region. It was found that this method had potential in determining impact and likelihoods of such events that plays a role to the flood risks (Lamb et al., 2010).

In a changing world Fluvial flood risk management was mainly due to interaction of hazard and vulnerability. Now it was believed that it was due to flood management decisions which were accepted and was made operational by utilizing quantified risk analysis and models which help in making risk-informed decisions. They suggested a range of directions that might be considered for decision making of nonstationary quantities which are uncertain; rules that were used to identify favoured option for flood risk management, multiple functions and hazards of river basins and for social and organizational characteristics that encourage adaptive capacity (Merz et al., 2010).

A review on economic flood damage Assessment was conducted to know current and finds economic flood damage valuation research direction. The results showed that damage assessments were contingent on various norms like selection of temporal and spatial boundaries, drawbacks in economic evaluation as choice between depreciated value and replacement cost. More work on empirical and synthetic data collection and for providing more consistent and reliable data to scientists were recommended. Uncertainty analyses and thorough scrutiny must be done for individual damage model development and its allied application. They found that risk assessments of flood were frequently not well balanced (Merz et al., 2010).

An experiment was designed to see the impact of upland land management on flooding by selecting improved pasture hillslope. The selected experimental area of plot, hillslope and small catchment scale were $\sim 100 \mathrm{~m} 2, \sim 0 \cdot 1 \mathrm{~km} 2$ and $\sim 10 \mathrm{~km} 2$, respectively. The result showed that Hill slope-scale data, from an under-drained, agriculturally 'improved' pasture had dominant runoff, but, on ancestor moisture situation basis, overland flow might exceed drain flow rates and could be a good giver to peak flow runoff at the hillslope-scale. Comparisons of pasture runoff with old tree shelterbelt showed much reduction in overland flow due to trees while comparisons of soil hydraulic properties depicted enhanced hydraulic 
conductivity and saturated moisture content of soil under trees in comparison with adjacent improved pasture (Marshall et al., 2009).

A detail review was conducted for land use, flood risk management. It was documented that land and water management were inextricably related with each other. A detailed analysis work was accessible for flood risk, from the Foresight Future Flooding project although it did not cover important topic of water demand (Defra, 2004; Evans et al., 2004; Wheater and Edward, 2009).

Assessment of flood risk arising from coastal sources and fluvial, a method was developed for local level flood risk assessment. This method needed flooding concerns scenarios linked with various defence section failures and severity flood events. This method was applicable, where outcome involving defences attributed, flood risk spatial map and left over risk had been used to sustain decision related to flood risk management planning for future (Gouldby et al., 2008).

A work on Flood hazard and management perspective was conducted in UK, Urban development was referred to boost fluvial flood frequency so design measures were regularly applied to reduce its effect. New methods research was required to assess and flood risk management. The land management also plays an important role in flood risk management. Climate change impact on flooding was also studies along with reassessment of flood hazard which led to better flood protection (Wheater, 2006).

The current study has been conducted for method development relating management of flood water from hill torrents area of Mithawan with main objectives of: reduction in damages to infrastructure and at the same time using the water for irrigation supplies and ultimately farmers' income and socioeconomic uplift of the area.

\section{Materials and Methods}

\section{Site description}

The Mithawan Hill Torrent is one of the 13 Major Hill Torrents (Mithawan Hill Torrent, Kaura Hill Torrent, Vehova, Sanghar, Sori Lound, Vidore, Sakhi Serwar, Chachar, Kaha, Pitok, Sori Shumali, Zangi and Sori Janubi) in Dera Ghazi Khan District of
Pakistan (Figure 1). The catchment area of Mithawan Hill Torrent is $800 \mathrm{~km}^{2}$ and located towards eastern slopes of Suleman Ranges. The gross command area under Mithawan is $165 \mathrm{~km}^{2}$ (40,726 Acres). The average rainfall is about $250 \mathrm{~mm}$ (10 Inches) over the high slopes of Suleman Mountain where the hill torrents rise.

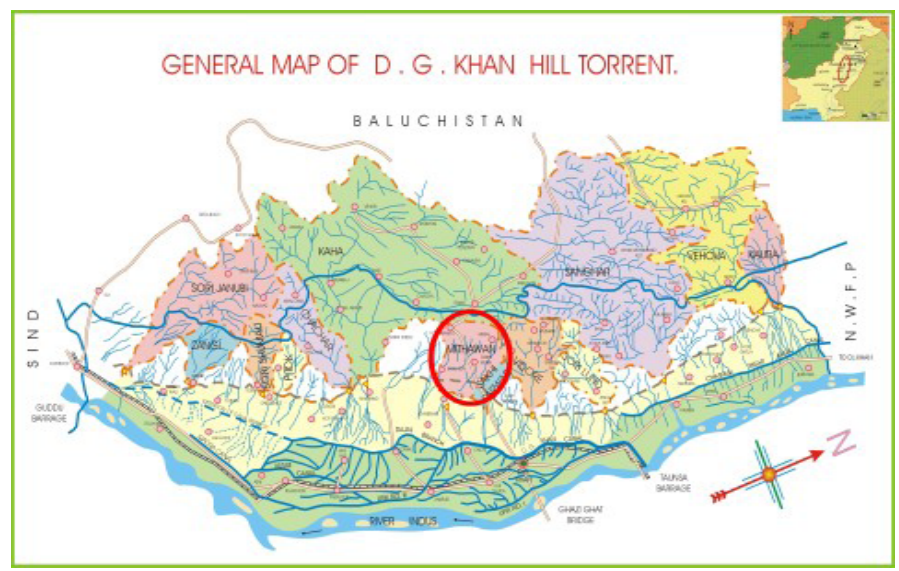

Figure 1: Map showing location of study site.

Table 1: Structure No.1 North Branch (RD. 24000, Q = 14000 Cusecs).

$\begin{array}{lll}\begin{array}{l}\text { Sr. } \\ \text { No. }\end{array} & \text { Name of Wah } & \begin{array}{l}\text { Discharge } \\ \text { (Cusecs) }\end{array} \\ 1 & \text { CHALGARI WAH / MISTING WAH. } & 6000 \\ 2 & \text { KOHRI WAH / DONG WAH. } & 3000 \\ 3 & \text { LANJWANI / TAHIR WAH } & 5000\end{array}$

\section{Methodology for management of Mithawan hill torrent} Traditional maintenance methods for channels and farm lands which have been constructed by the local farmers through observing variation in the channels and minimizing harm events are important basic techniques for the future maintenance on the fan. For this purpose, following approach and methodology were followed under the current study.

- To avoid concentration of flood flows into a specific channel by dispersing flows over the fan by means of distributor on the fan head.

- To divert flood flows into the bund in a secure manner.

- To assure storage in each bund.

In addition, the followings measures were adopted to use flood flows effectively and to decrease flood damage.

- To strengthen the right bank of D.G. Khan canal for prevention of flooding in the canal irrigated area. 
- To provide reservoir area on the mid-fan for effective use of the water by expanding available duration to use flood water.

The layout plan of Mithawan Hill Torrent is shown in Figure 2 giving flow direction.

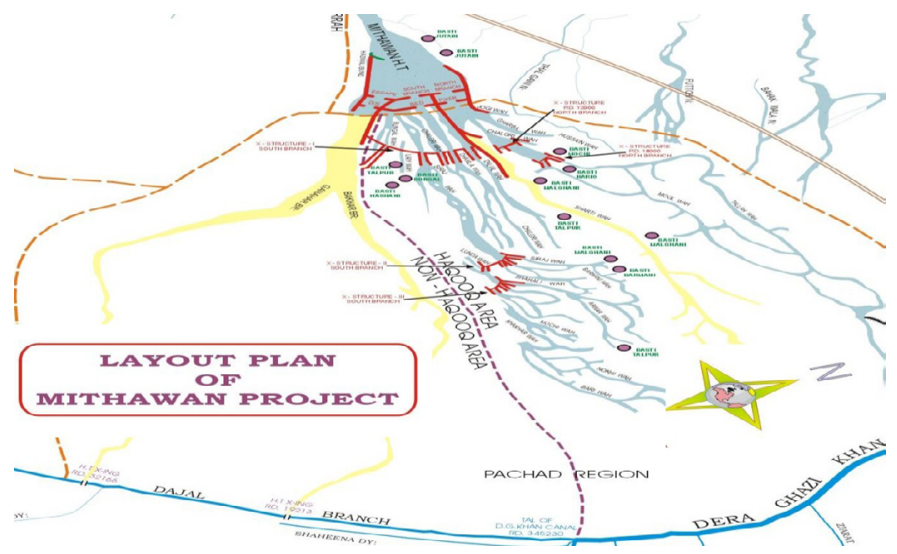

Figure 2: Layout Plan of Mathawan Hill Torrent showing flow direction.

Table 2: Structure No.2 North Branch (RD. 29000, Q $=8700$ Cusecs).

$\begin{array}{lll}\text { Sr. No. } & \text { Name of Wah } & \text { Discharge (Cusecs) } \\ 1 & \text { BEHU WAH } & 4200 \\ 2 & \text { NOKH WAH } & 300 \\ 3 & \text { HUSSAIN WAH } & 200 \\ 4 & \text { TALLAH WAH } & 4200\end{array}$

Structural measures for management of Mithawan bill torrent

Under this study, following structures were proposed to overcome the basic problem of the area due to hill torrent

Main distributor structure: In order to expand hill torrent flood over Mithawan region, as well as mitigate the flood damage in D.G. Khan Canal irrigated area, the main distributor structure was proposed.

Downstream bed fixer: In order to control the hill torrent water for management structures, downstream bed fixer was proposed.

Management structures: As part of the structural measures, five numbers of management structures were proposed (Figures 4, 5, 6 and 7 and their related information presented in Tables 1, 2, 3 and 4) which are:

- X - Structure \# 1, North Branch (Figure 4 and
Table 1)

- X - Structure \# 2, North Branch (Figure 5 and Table 2)

- X - Structure \# 3, South Branch (Figure 6 and Table 3)

- X - Structure \# 4, South Branch (Figure 7 and Table 4)

- X - Structure \# 5, South Branch (Figure 7 and Table 5)

The location of the all structures is shown in following line-diagram (Figure 3).

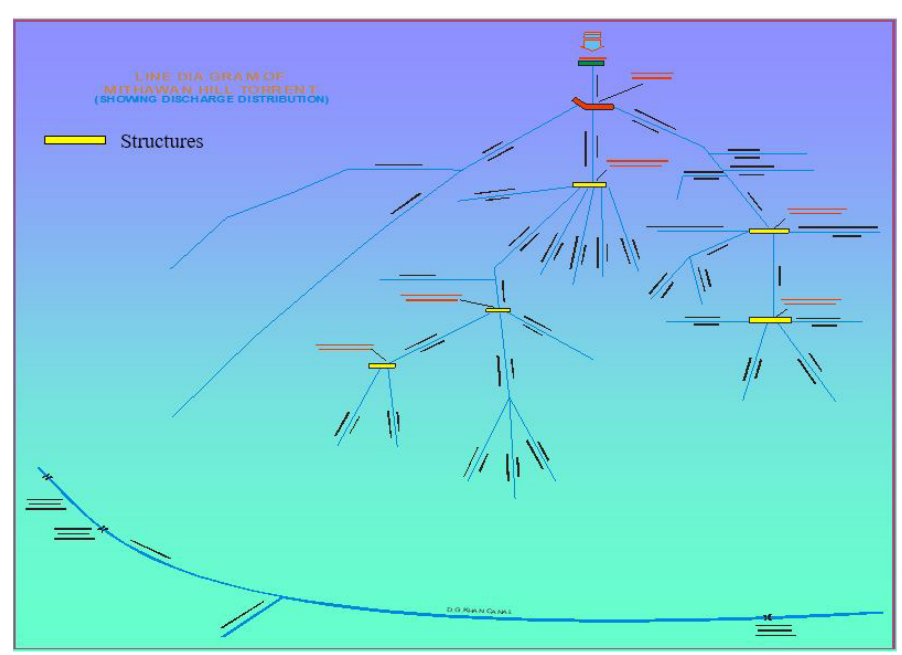

Figure 3: Line Diagram showing discharge distribution and structures.

Table 3: Structure No.3 South Branch (RD. 21000, $Q=$ 15000 Cusecs).

$\begin{array}{lll}\text { Sr. No. } & \text { Name of Wah } & \text { Discharge (Cusecs) } \\ 1 & \text { DALAIL WAH } & 1500 \\ 2 & \text { KHONDO WAH } & 500 \\ 3 & \text { CHALGARI WAH } & 1000 \\ 4 & \text { DHAMIA WAH } & 500 \\ 5 & \text { SIRAJ WAH } & 11000 \\ 6 & \text { BUNGAL WAH } & 500\end{array}$

\section{Main issues/Problems of management structures}

The following issues were faced and accordingly handled while proposing the structures.

- Construction of management structures is extremely complicated regarding water rights.

- Proper investigation regarding water rights of the off taking channels have to be establish for fair distribution of water of according to SaropaPiana* principal (water right act of 1906)

*Saropa-Piana. This law basically provides that the 
upstream users will always have the priority rights over downstream users.

\section{Management effects on the Mithawan bill torrent}

The aim was the reduction of flood damages in the canals irrigated areas by enhancing flood irrigation in the Pachad. The effect of management of Mithawan Hill torrent could be measurement by increase in the crop production and decrease of the flood damages.

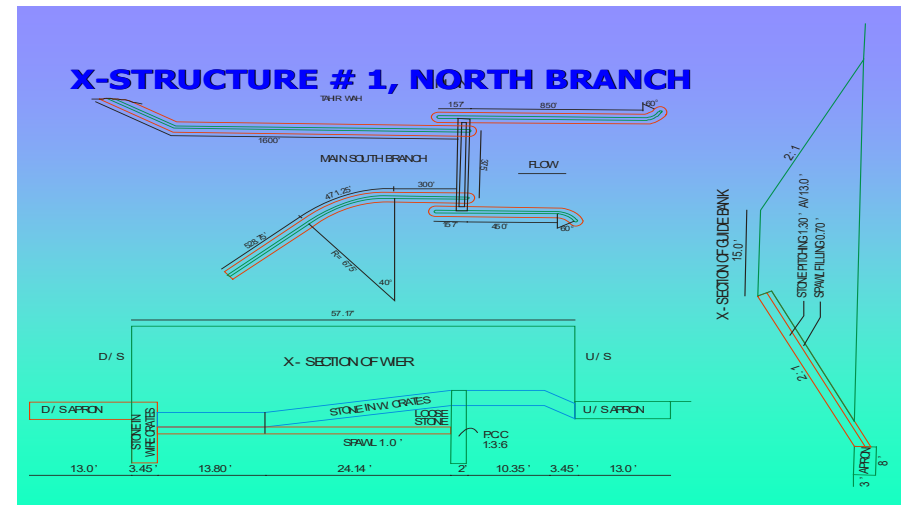

Figure 4: Mathawan Hill Torrent Management Structure No.1, North Branch.

Table 4: Structure No.4 South Branch (RD. 38000, $Q=$ 10700 Cusecs).

\section{Sr. Name of Wah}

No.

1 SIRAJ WAH

2 BIRMANI WAH

3 TALPUR WAH

4 VILANGA WAH / SHAHALI WAH

5 UTWAN WAH

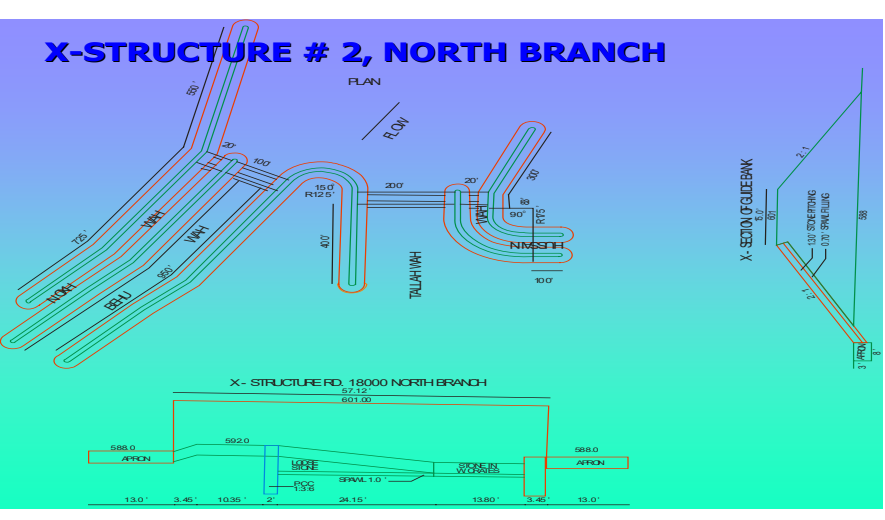

Figure 5: Mathawan Hill Torrent Management Structure No.2, North Branch.

Table 5: Structure No.5 South Branch (RD. 40000, Q $=7000$ Cusecs).
Sr. No. Name of Wah
1 UTWAN WAH
Discharge (Cusecs)
2
LUNDA WAH

$\begin{aligned} & \text { Discharge } \\ & \text { (Cusecs) }\end{aligned}$
700
1000
1000
1000
7000

Increase of crop production

The crops cultivated in the Pachad area are Jowar and Bajra for Kharif crops and wheat, gram and oil seeds for Rabi crops. The area of flood irrigation varies with extent of floods and it is expected to be expanded by construction of main distributors and management structures. The average annual crop production will be 400 millions.

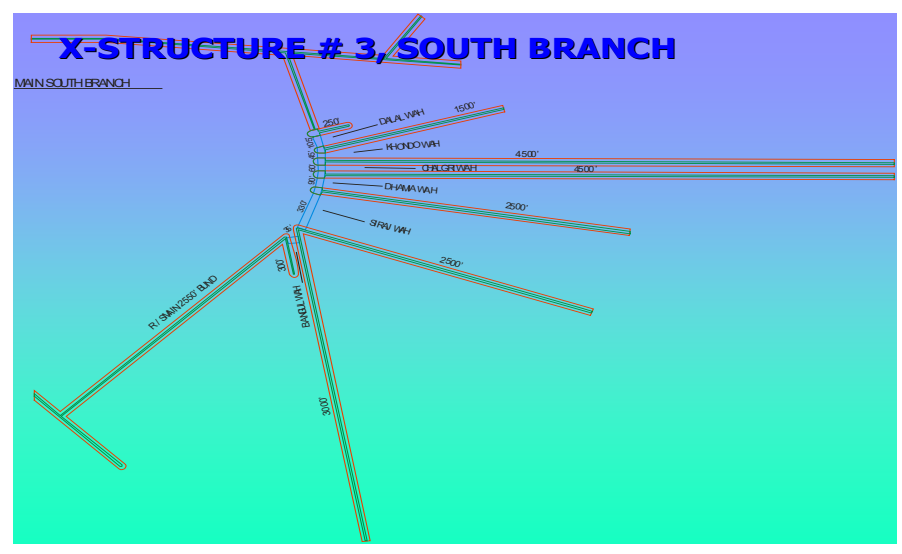

Figure 6: Mathawan Hill Torrent Management Structure No.3, North Branch.

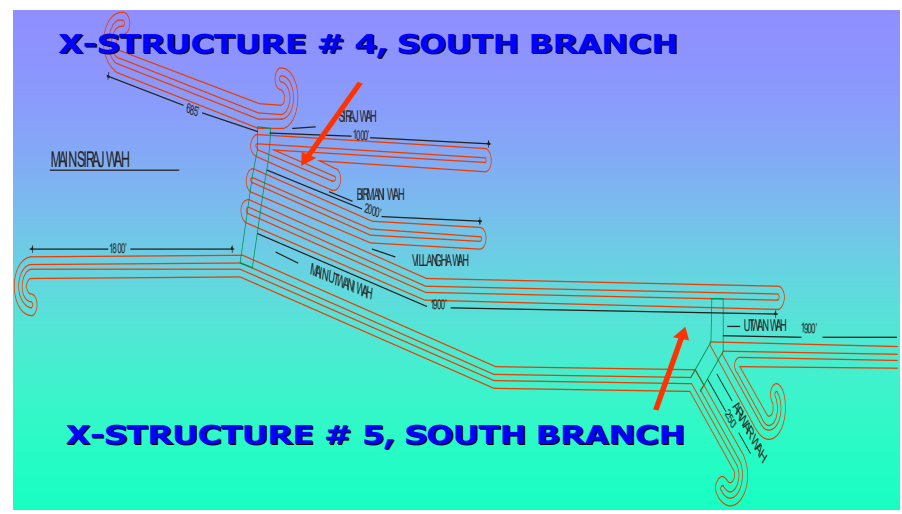

Figure 7: Mathawan Hill Torrent Management Structure No.4, South Branch.

\section{Reduced flood losses}

The canal irrigated area by the D.G. Khan Canal is extended over both D.G. Khan District and Rajanpur District. Damaged by the flood was estimate by the feasibility study for flood protection of Tounsa Gudu Reach of Indus River.

The feasibility study of Mithawan for management in 1984 estimated flood area is about $320 \mathrm{~km}^{2}(32000$ ha). Share of Mithawan Hill torrent to the total flood losses is estimated $35 \%$ since the heavy rain causing flood losses tends to pour simultaneously over the D.G. Khan Hill torrent belt.

\section{Benefited population}

Population in the Pachad is estimated about 42,000

September 2021 | Volume 34 | Issue 3 | Page 443 
and all of them will be benefited by irrigation. Number of beneficiaries by flood protection is estimated about 94,000 . In canal irrigated area assuming affected area of $113 \mathrm{~km}^{2}$ at the return period of 25 years and 43 houses per $\mathrm{km}$ with average family number of 15 .

\section{Conclusions and Recommendations}

The major conclusions of the study are as under;

- Reduction in damages to infrastructure in the area

- Canal breaches will stop

- Damages to the standing crops in canal command area will be minimized

- Enhanced irrigation supplies in the Kohe Suleman (Pachad) area by means of improved management measures (3 to 5 Lac cusecs hill torrent flood water was wasted every year and discharged into the Indus River without any proper utilization)

- Enhanced cultivable area (only $11 \%$ area was being cultivated of surrounded hill torrents area (about $800 \mathrm{~km}^{2}$ ) due to lack of proper management)

- Improvement in the economic condition of the area

- Established stable forming in the Pachad area i.e. plain area in the foot hill of Koh e Suleiman.

- Make maximum use of flood water for agricultural to increase production.

- Construction of Management Structures for Hill Torrents will provide equitable distribution of irrigation water.

It is recommended that:

- To establish a new Government department to properly survey the mountainous region in order to manage the hill torrent flood water.

- A thorough investigation and survey is required to locate the proper sites for the small dams and the onward management of stored water as proposed under the study.

\section{Novelty Statement}

The study presents management solution of Mithawan hill torrent flood water by constructing main dispersion distributor and management structures for equitable distribution in the plain area of the foot hills of Kohe-Suleiman. Management solution provided efficiently use of water for irrigation purposes towards agriculture livelihood enhancement. The developed procedure can be applied for hydrologic/hydraulic planning and preliminary design of water resources development projects and designing of various hydraulic structures.

\section{Author's Contribution}

Talat Farid Ahmed: Data collection, conducted research and wrote the paper.

Shamim-ul-Sibtain Shah: Overall guidance and literature review of research.

Ashfaq Ahmed Sheikh: Incorporated reviewer's comments and technical support.

Hashim Nisar Hashmi: Overall supervision of research.

Muhammad Atiqullah Khan: Statistical analysis of data, helped in references and review of paper.

Muhammad Azeem Afzal: Supported in analytical work, design and implementation of the research and also helped in writing of the manuscript.

Conflict of interest

The authors have declared no conflict of interest.

\section{References}

Abily, M., N. Bertrand, O. Delestre, P. Gourbesville and C.M. Duluc. 2016. Spatial global sensitivity analysis of high resolution classified topographic data use in 2D urban flood modelling. Environ. Model. Softw., 77: 183-195. https://doi. org/10.1016/j.envsoft.2015.12.002

Defra, 2004. Making space for water: developing a new government strategy for flood and coastal erosion risk management in England: a consultationexercise. https://www.defra.gov.uk/ environ/fcd/policy/strategy.htm.

Dorgigné,Y.,M.Abily,L.Salvan and P.Gourbesville. 2018. Creation and life of an operational crisis management centre in nice metropolis: Consolidation of flood events handling using feedbacks following the $3^{\text {rd }}$ October flood event. Adv. Hydroinf., Springer, Singapore. pp. 483-496. https://doi.org/10.1007/978-981-107218-5 34

Economic Survey of Pakistan 2018. Government of Pakistan www.finance.gov.pk/survey/ chapters_18/Economic_Survey_2017_18.pdf Accessed on 07-05-2019.

Evans, E., R. Ashely, J. Hall, E. Penning Rowsell, P. Sayers, C. Thorne and A. Watkinson. 2004. Foresight future flooding, Volume I and Volume II. Office of Science and Technology, London. 
Farooq, S., R. Kausar, A. Ashraf and B. Haider. 2020. Exploring surface runoff potential and water harvesting sites in Dera Ismail Khan Rod-kohi Area Using GIS and remote sensing. Proc. Pak. Academy of Sciences: A. Physical and Computational Sciences, 57(2), 1-10.

Gouldby, B., P. Sayers, J. Mulet-Marti, M.A.A.M. Hassan and D. Benwell. 2008. A methodology for regional-scale flood risk assessment. Proc. Inst. Civil Eng. Water Manage., Thomas Telford Ltd. 161(3): 169-182. https://doi.org/10.1680/ wama.2008.161.3.169

Lamb, R., C. Keef, J. Tawn, S. Laeger, I. Meadowcroft, Surendran and C. Batstone. 2010. A new method to assess the risk of local and widespread flooding on rivers and coasts. J. Flood Risk Manage., 3(4): 323-336. https:// doi.org/10.1111/j.1753-318X.2010.01081.x

Marshall, M.R., O.J. Francis, Z.L. Frogbrook, B.M. Jackson, N. McIntyre, Reynolds and J. Chell. 2009. The impact of upland land management on flooding: results from an improved pasture hillslope. Hydrol. Proc. Int. J., 23(3): 464-475. https://doi.org/10.1002/hyp.7157

Merz, B., J. Hall, M. Disse and A. Schumann. 2010. Fluvial flood risk management in a changing world. Nat. Hazard. Earth Syst. Sci., 10: 509-527. https://doi.org/10.5194/ nhess-10-509-2010

Merz, B., H. Kreibich, R. Schwarze and A. Thieken. 2010. Review article. Assessment of economic flood damage. Nat. Hazard. Earth Syst. Sci., 10(8): 1697-1724. https://doi.org/10.5194/ nhess-10-1697-2010
Munir, B.A., S.R. Ahmad and R. Rehan. 2021. Torrential flood water management: Rainwater harvesting through relation based dam suitability analysis and quantification of erosion potential. ISPRS Int. J. Geo-Inf., 10(1): 27. https://doi.org/10.3390/ijgi10010027

NESPAK, February 1996. Master feasibility / flood management of D.G. Khan Hill Torrents.

Psomiadis, E., L. Tomanis, A. Kavvadias, K.X. Soulis, N. Charizopoulos and S. Michas. 2021. Potential dam breach analysis and flood wave risk assessment using HEC-RAS and remote sensing data: A Multicriteria Approach. Water, 13(3):364.https://doi.org/10.3390/w13030364 Randall, M., N. Perera, N. Gupta and M. Ahmad. 2017. Development and calibration of a dual drainage model for the Cooksville Creek watershed, Canada. J. Water Manage. Model., https://doi.org/10.14796/JWMM.C419

Rural and Urban Area Classification, 2004. An introductory guide the country side Agency, Department for Environment, Food and Rural Affairs, 2004 - Office for National Statistics London.

Wheater, Howard S., 2006. Flood hazard and management: A UK perspective. Philos. Trans. R. Soc. London A: Mathemat. Phys. Eng. Sci., 364(1845): 2135-2145. https://doi. org/10.1098/rsta.2006.1817

Wheater, Howard and E. Evans. 2009. Land use, water management and future flood risk. Land use policy 26 (2009): S251-S264. https://doi. org/10.1016/j.landusepol.2009.08.019 